- the blood of most autistic children - but not in healthy children - DNA sequences that emit, in certain conditions, electromagnetic waves."

Montagnier defends his research, pointing out that some clinicians have observed improvements in symptoms of autism after long-term treatment with antibiotics. He says that he has never argued that vaccination could cause autism. "Many parents have observed a temporal association, which does not mean causation, between a vaccination and the appearance of autism symptoms," he says. "Presumably vaccination, especially against multiple antigens, could be a trigger of a pre-existing pathological situation in some children."

\section{LEADERSHIP CRISIS}

The CIRCB, founded in 2006, is named after President Biya's wife, who has championed efforts to fight AIDS in Africa. Montagnier's AIDS foundation was a founding partner; Montagnier is also president of the nowdefunct scientific advisory board, and vicepresident of the management board.

The current crisis compounds problems caused by the centre's lack of stable full-time leadership. In March, its management committee appointed Montagnier to replace former interim scientific director Vittorio Colizzi, an AIDS researcher on secondment from the Tor
Vergata University in Rome, who had held the post since 2009. Colizzi was standing in until a full-time scientific director could be hired, but a recruitment process last year failed to settle on an agreed candidate. Some candidates had also expressed misgivings about the job, because at the time the scientific director and administrative director had to share power, a situation that caused tensions, says Colizzi. To address this issue, a presidential decree issued on 31 May merged the positions to create the post of permanent director, with full control of the centre. The move should make it much easier to attract a leading scientist to the post, says Jacques Theze, an immunologist at the Pasteur Institute in Paris, a former member of the CIRCB's scientific board.

The decree also required that many of the centre's posts and committees be disbanded or renewed, creating an uncertain transitional period. On the day that Roberts resigned, for example, the scientific board was officially dissolved, and no clear timetable has been set to reestablish it. Colizzi is concerned that this deprives the centre of its main mechanism for enforcing rigorous peer-review and ethical oversight of research proposals. Montagnier says that he intends to continue all research previously approved by the board, and that he will ask the next board to review the programme. He also plans to embark on new research, including a "key project" using his electromagnetic-wave theory to detect reservoirs of HIV in the body that persist after antiretroviral treatment. Any new projects, including his own, will need to be approved by the centre's science board and ethics committee, he says.

Jean Stéphane Biatcha, head of the centre's management board and a presidential adviser, recognizes the "very serious disagreement" but says that the president and the Ministry of Health will quickly enact the 31 May decree, and so will renew the scientific advisory board and begin the search for a permanent director.

Theze says that he would have preferred Montagnier's detractors to have taken a more diplomatic approach, and warns that the highlevel criticism, and the resulting controversy, risks tarnishing the credibility and reputation of the centre, which he says is unfair, because the CIRCB has enormous potential. He worries that the episode might also discourage scientists from applying for the position of director. -

1. Montagnier, L., Aïssa, J., Ferris, S., Montagnier, J.-L. \& Lavalléee, C. Interdisciplin. Sci. 1, 81-90 (2009).

2. Montagnier, L., et al. Preprint at http://arxiv.org/ abs/1012.5166 (2010).

3. Montagnier, L. et al. Interdisciplin. Sci. 1, 245-253 (2009).

4. Butler, D. Nature 468, 743 (2010).

\title{
PUBLISHING
}

Britain aims for
broad open access

\section{But critics claim plan seeks to protect publishers' interests.}

\section{BY RICHARD VAN NOORDEN}

$\mathrm{F}$ or years, countries have been edging towards open access for research, with some funding agencies requiring that researchers make their papers publicly available within a set period after publication. A report commissioned by the UK government recommends a more radical step: making all papers open access from the start, with authors paying publishers up-front to make their work free to read.

The shift towards this 'gold' form of open access will create short-term financial burdens for research funders, the report acknowledges, but the economic and cultural benefits far outweigh the risks. Not everyone is convinced, however: research-intensive universities say they are concerned that the report plays down potentially cheaper ways to move to open access, in favour of sustaining publishers' profits.

"Momentum for open access is already under way, and it's important for the United Kingdom to embrace that change, to accelerate it, and to manage it," says Janet Finch, a sociologist at the University of Manchester, UK, who chaired the panel behind the report, which was released on 19 June. It is expected to set the national agenda for open access, and influence other countries to follow Britain's lead.

"The ultimate goal is to have a system where the full costs of research publication are met in advance," says Martin Hall, another member of the panel and vice-chancellor of the University of Salford in Manchester. Globally, the number of gold articles is growing by about $30 \%$ each year, aided by the rise of journals such as PLoS ONE. But they still make up a minority of the world's output - comprising about $12 \%$ of research articles indexed in Elsevier's Scopus

database in 2011, according to preliminary estimates by Mikael Laakso and Bo-Christer Björk at the Hanken School of Economics in Helsinki (see 'Rise of gold'). UK researchers tend to publish in higher-impact selective journals, so only $5 \%$ of their articles are gold open access, according to data collected by Yassine Gargouri, a informatician at the University of Quebec in Montreal, Canada (see 'Open access in the UK').

As that proportion rises, the report notes, authors' open-access costs will grow - but university libraries will still have to subscribe to most of the journals that currently line their shelves. Subscription costs will fall substantially only when most research articles are freely available. During the transition period, gold and subscription models will exist side by side, potentially increasing the overall costs of access. The report also recommends subsidising subscription licences for health and business users to give them better access. Overall, the panel estimates that these transitional costs will amount to roughly $£ 50$ million-60 million (US\$78 million-94 million) per year, on top of the country's existing annual spending of about $£ 175$ million to publish and access research. If the costs were to be met by research funders,

DNATURE.COM For Nature's policy on open access, see: go.nature.com/pnxzup they would total about $1 \%$ of Britain's annual science budget.

The report does not recommend a figure for 
the cost of a gold article, but notes that the UK Wellcome Trust, a major biomedical research funder, last year paid an average of $£ 1,422$ per paper on behalf of the scientists it supports. Costs could be greater in more selective journals - Nature's editor-in-chief Philip Campbell says that the journal would have to charge more than $£ 6,500$ for gold open-access articles.

Universities and funders will have to work out how to transform their payment systems under a gold regime, with each institution likely to set up a central publishing fund supported by a percentage of every research grant. Whatever the solution, academics will be much more aware of the costs of publishing. This could, in turn, modify their behaviour, with researchers submitting papers to the journals they can afford to publish in, or trying to publish fewer, broader articles.

\section{GOING GREEN}

An alternative open-access model is already thriving around the world, and particularly in the United Kingdom. Under green open access, research funders can require that peerreviewed papers be made openly accessible in online repositories, without the author paying a fee. This usually happens some months after publication, a time period that allows publishers to sell access to the paper for long enough to turn a profit. Researchers can also post prepublication versions of their papers in institutional repositories.

Paul Ayris, director of library services at University College London, says that scaling up green publishing would be a cheaper shortterm route to expanding open access, together with a nationwide scheme to pay for researchers' access to subscription journals en masse. "The gold route does nothing about publisher profits, which many commentators feel are already too high," he says. Open-access advocate Stevan Harnad, a cognitive scientist at the University of Montreal, is even more critical of the report's overt support for gold access. "Some publishers seem to be successfully persuading some politicians that what is at issue is protecting their current revenue streams and modus operandi from the threat of green open access," he says.

But the Finch group says that it was expressly asked to find sustainable ways to grow open

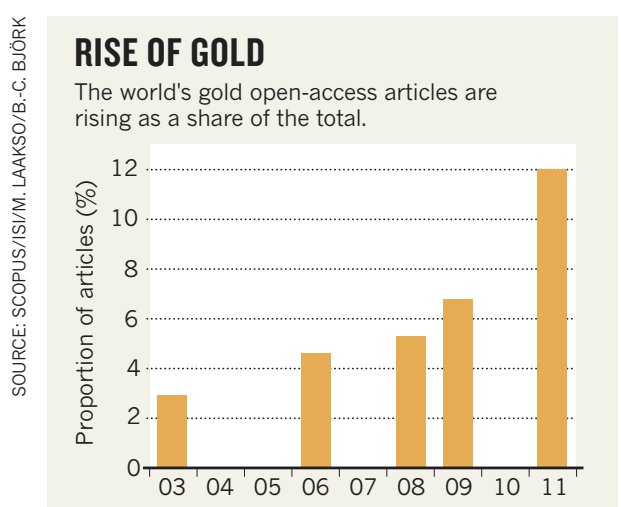

\section{OPEN ACCESS IN THE UK}

Of the 85,215 research papers published by UK academics in 2010 (as indexed by Web of Science), around 5\% were gold open access, whereby authors pay for open publication. Another $35 \%$ were green open access published behind a pay wall and then put in a free repository. However, the proportion varied between disciplines.

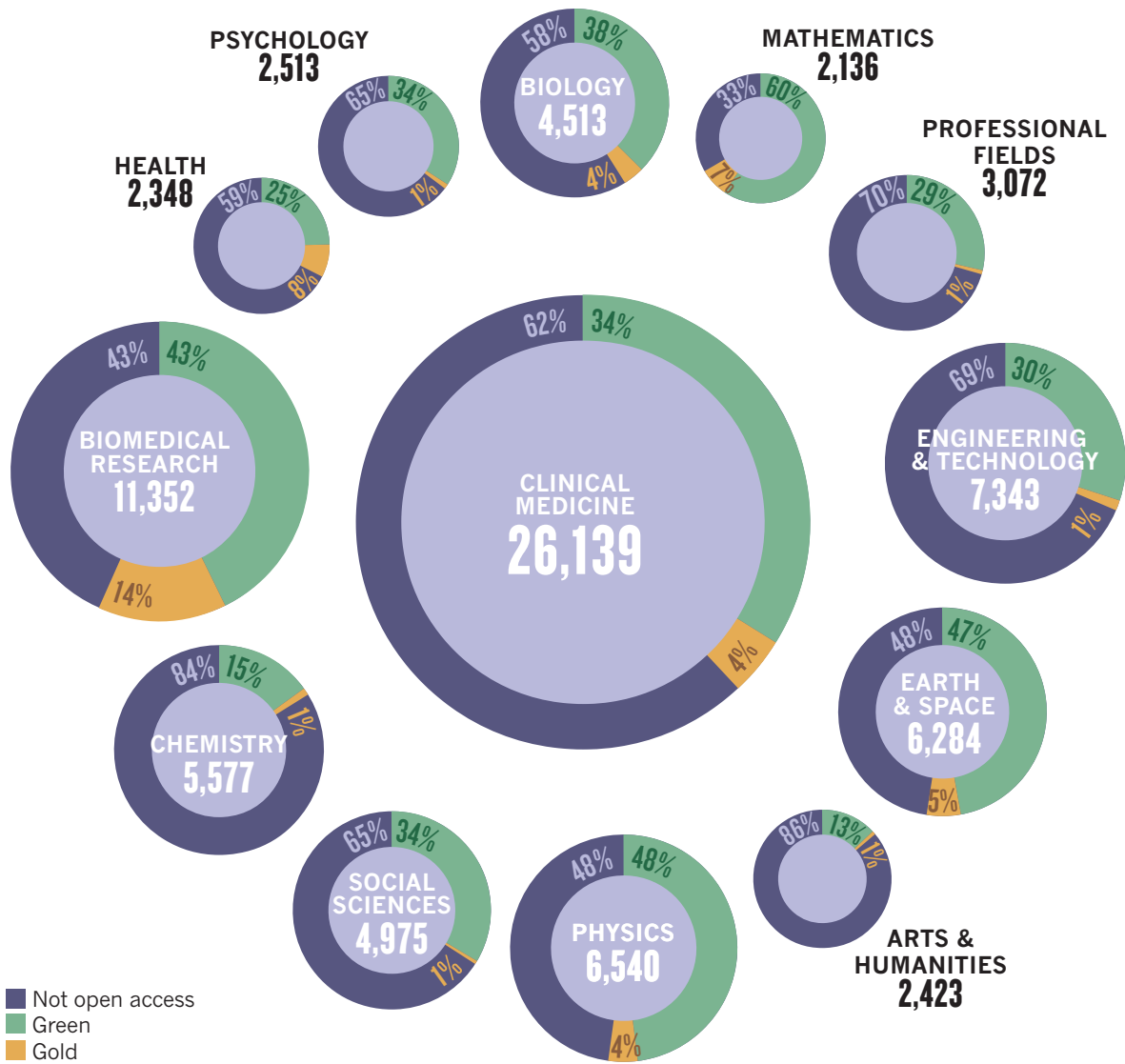

access, which it says only a gold route can provide. "It's not in the interests of UK scholarship to make recommendations which undermine the sustainability of the publishing industry," says Philip Sykes, another Finch group member and a librarian at the University of Liverpool. Universities can use their collective lobbying power to drive down both subscription and gold costs, he adds. Gold open access will eventually result in lower incomes for publishers anyway, Finch members note, by making the research-publishing market more transparent and competitive.

That's particularly worrying for learned societies, because they rely on subscription publishing for much of their income. The London-based Institute of Physics, for example, earns some $£ 10$ million each year - more than $60 \%$ of its total income - from publishing, which it spends on activities such as science education and outreach, says its president Peter Knight. "The mood of the community is to get costs down - but if scientific publishing only just covered its costs, an awful lot of our programmes would be in jeopardy," he says.

What matters now is how the agencies that support UK scientists require them to make their research freely available. Existing openaccess mandates have been spottily enforced. The Wellcome Trust has only 55\% compliance, although it will soon make grant funding conditional on open-access publishing. A similar condition from the US National Institutes of Health currently has 75\% compliance.

In March, Research Councils UK (the umbrella body for the United Kingdom's seven government-funded grant agencies) released a draft policy that suggested it, too, would toughen up on open access. The Higher Education Funding Council for England, another major research funder, could go the same way. But the devil will be in the detail, says Hall. "If research funders go soft on open access, the Finch report will be of only academic interest."

Most uncertain of all is how rapidly the United Kingdom's efforts might drive other countries towards open access. British scientists produce $6 \%$ of the research papers published worldwide each year, and the country could find itself paying to make its research free for others' benefit. But there is growing momentum internationally. The European Commission hopes to push for an open-access mandate in its 2014-20 research-funding programme Horizon 2020, and the newly formed Global Research Council - a forum for funding-agency heads worldwide (see Nature 485, 427; 2012) - has open access on its agenda for its second meeting next year in Berlin. As the report concludes, "measures to promote open access need to be ... international in scope if they are to achieve their full potential". 